\title{
Economic, social and environmental world impacts of food waste on society and Zero waste as a global approach to their elimination
}

\author{
Andrea Seberini ${ }^{1}$ \\ Matej Bel University, Faculty of Economics, 97401 Banská Bystrica, Sovakia
}

\begin{abstract}
The aim of the article is an effort to introduce readers to the problem of food waste in a comprehensive concept. It focuses on defining concepts, defining losses in the different phases of the food chain together with their environmental, economic and social impacts to the society. It also presents proposed or already applied solutions in connection with the effort to reduce food waste. More than 14 million tonnes. This is the amount of waste produced by Slovakia in 2018. Of this 2.1 million tonnes was municipal waste, which represents $393 \mathrm{~kg}$ per inhabitant per year. Unfortunately, this number is growing every year. Zero Waste concept encourages consumers to reduce consumption and recycling of acquired goods and materials, which in economic and social terms can bring regression under certain circumstances, to the detriment of environmental progress. If we do not begin to rationally analyze our own needs and at the same time intelligently manage the waste that we, as a human being, produce globally, we are at risk of significantly reducing the comfort of living. I assume and believe that this is not a vision that we would like to leave to future generations.
\end{abstract}

\section{Introduction}

Waste generation is gaining momentum in the 21 st century. It is not a small measure of spoiled and often unused food.Food waste and the problems of waste of food is a sub-area of action of food law not only at European level. The waste that occurs at all levels of the food chain has enormous implications for many sectors of life, which will be further elaborated later. The wastage or depreciation of food is gaining ground primarily in countries of 'welfare', where consumers

\footnotetext{
${ }^{1}$ Corresponding author: andrea.seberini@umb.sk
} 
have the choice of a wide range of foods. It is also clear that this is a global problem that is becoming increasingly political and social. It is not only a waste of valuable nutritional resources, but also of water, land, capital and energy. It has a negative impact on the environment and the economy of individual countries. The average consumer is likely to see primarily the amount of money she/he has paid for the product in the store under the discarded piece of food. However, few people think about the context, how many phases and often countries had to go through a piece of food before the customer could buy it in the store and what all these activities are ultimately redeemed. One of the responses to this situation on an individual level is the phenomenon of zero waste. Zero waste is the idea and strategy of zero waste that leads people to change their lifestyle and their daily practices. Zero waste is a visionary goal and a solution to prevent waste generation in today's society. With the mass production of waste that society cannot manage, moral aspects come, especially from an environmental point of view. The main role in the increasing generation of waste is the issue of contamination and its impact on all individuals, human society and the environment. Related to this is the question of how to treat these wastes in a technological way so that they no longer act as waste [10]. We have reached a stage where the amount of waste becomes an environmental problem. The aim of this work is to bring new knowledge about waste reduction and zero waste as and global approach to their elimination. The benefit of this work is to familiarize the reader with the topic of zero waste and at the same time reveals the economic, social and environmental impacts of food waste.

The cost of wasting food is also a waste of valuable resources, water, energy, fuel and human labor. As a result, wasting becomes an economic, environmental and socio-ethical problem. I aim to raise their awareness of the importance and possibilities of preventing and reducing food waste.

\section{Global food waste}

The Food and Agriculture Organization - FAO, states that approximately one third of the world's food is degraded or discarded. If we look closely at the figures, it is 1.3 billion tons for about 990 billion USD.Fruits, vegetables, root and tuber fruits (about $45 \%$ of food grown), fish and seafood (35\%) and cereals (30\%) are the most wasted [5].Loss of food is defined as: "reduction in the quantity or quality of food [5]. Food waste is part of food loss and refers to the ejection or alternative (non-food) use of safe and nutritious foods intended for human consumption that take place throughout the food chain from primary production to final household consumption[5]. The distinction of food losses can be found, for example, in Global Food Losses and Food Waste [9]

- Food loss is considered to be food that was originally intended for human consumption but has been devalued due to various factors at the stage of production, harvest and processing. Most of these losses are linked to inefficient storage, inappropriate infrastructure and logistics, and adverse climatic conditions. Developing countries have the highest share of food waste in these early stages of the food chain.[1]

- Food waste: food waste is characteristic of the later stages of the food chain. Specifically, the distribution, retail and end-use phases in households 
or restaurants. This is mostly due to the expiration of the expiration period or simply because of the ejection due to unawareness of consumer intervention (purchase of more goods than the consumer is able to use, unfinished residues, etc.).[1]

In the opinion of several authors $[7,8,9,17]$ exists specific classification for food loss and food waste. Food losses occur in the first stages of the food supply chain and are mainly due to poor technology and investments, which is why they specifically occur in developing countries. Food waste is related to the final consumption phase (household, consumption, retail etc.) and is a consequence of consumer's behaviour, therefore it is typical of the Western Countries. [8, 9, 17, 18]

A closer look at the whole food chain data reveals that there is greater loss at the beginning of the food chain in developing countries. These may be due to poor storage conditions, insufficient infrastructure and transport, poor packaging or technical equipment..In developed countries, food waste mainly affects the end recipients of food - shops and consumers, where the emphasis is on food quality and appearance [9]. In developed countries, consumers play a large role in the food supply chain, as it is reported that up to $40 \%$ of food is wasted in households, which is about ten times more than in developing countries. One of the main goals of United Nations Organisation activities is eradicating hunger, promoting sustainable agriculture and ensuring sustainable production and consumption. Wasting resources by losing and throwing away food as it passes through the food chain also inevitably wastes resources that have been used and consumed.This category includes waste of water, soil, energy, money and human labor [5]

\section{Consequences of food waste}

The average consumer is likely to see primarily the amount of money he has paid for the product in the store, under the discarded piece of food. However, few think of the context, how many phases and often countries had to go through a piece of food before a customer could buy it in the store and what all these activities are ultimately redeemed. Food production is one of the most resourceintensive industries and causes high emissions of harmful substances. By generating food waste, all sources used in the production, transport or distributions of food are degraded. Wasting food also wastes water, energy, soil and money, which implies their environmental impactThe specific consequences of food waste are described in the FAO's Food wastage footprint: Impacts on natural resources. [5]. Most often we categorize them for environmental, economic and socialimpacts. 


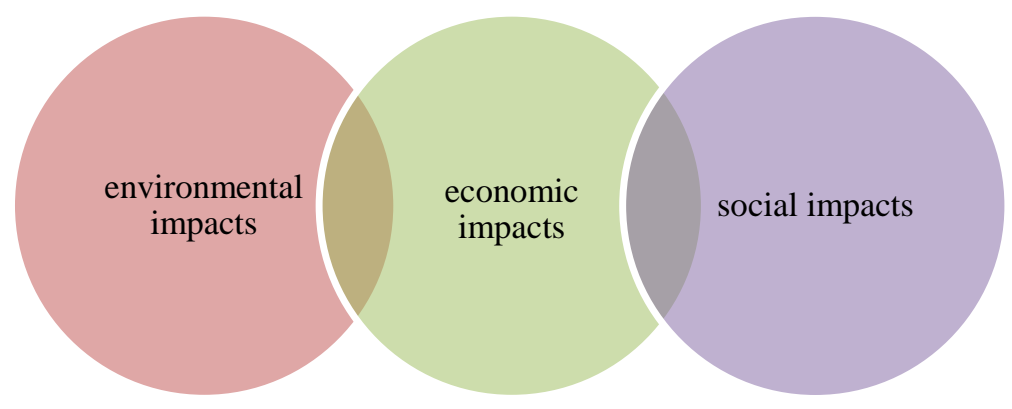

Fig. 1. Consequences of food waste[5]

\subsection{Environmental impacts of food waste}

The production of food that is not consumed has a significant impact on the environment. Uneaten parts of food in landfills contribute to global warming.Food waste decomposes, producing harmful methane that escapes into the atmosphere. Methane is one of the poisonous greenhouse gases and is 21 times stronger than carbon dioxide. Globally, gas from food dumps accounts for $7 \%$ of total greenhouse gas emissions.If these foods were properly composted, less harmful carbon dioxide could be released into the air instead of methane. Another factor, besides food dumps, which affects the environment is the distribution of food over longer distances or their subsequent disposal. These processes require a large volume of fuel, which in the long term is significantly affected by the emissions from the exhaust gases[6].Over the past decades, food waste has captured the attention of environmental associations, in addition to policy makers, analysts and researchers [15]. The FAO has implemented a project called Food Wastage Footprint (FWF), which demonstrates that reducing food waste is a logical priority to create more sustainable ways of producing and consuming food and providing a global overview of the environmental footprint along the food chain. The first phase of the project mapped the global footprint of waste to quantify impacts on the atmosphere, water, soil and biodiversity. The project used the Life Cycle Assessment (LCA) model to assess the extent of environmental impacts and to identify food commodities for regions and phases of the food chain where appropriate mitigation measures should be taken. The second phase of the FWF project measured environmental impacts on societal costs. It has developed a methodology to assess direct financial costs, the lost value of ecosystem goods and services and the loss of well-being associated with the degradation of natural resources. The total cost of food waste was found to be about $\$ 2.6$ billion per year, including environmental protection costs of $\$ 700$ billion and social costs of $\$ 900$ billion [5]

Global food security and supply is a real problem. Without sustainable mitigation strategies, increased food production will be reflected in increased GHG emissions through deforestation, as land is grabbed for food production [14], as well as increased waste production [12]. 


\subsection{Social impacts of food waste}

Although enough food is produced in the world, nearly a billion people worldwide suffer from hunger and malnutrition.Many developed countries throw away tons of food that could be consumed in developing countries.. These foods are thrown away even though they are still good quality and safe. Similar problems also occur within individual developed countries.Part of the population has sufficient access to food, up to their surplus, but on the other hand there are socially weaker groups of the population who do not have the opportunity to buy quality food, or sometimes they do not have enough food at all. At European level, according to the European Parliament's Committee on Agriculture, up to 50\% of edible and harmless food is unnecessarily depreciated and thrown away in European homes, supermarkets, restaurants and along the entire food chain every year.While 79 million citizens live below the poverty line and 16 million depend on food aid provided by charities [3]. It is proven that feelings of life fulfillment and satisfaction are not the result of the quantity of commodities owned and consumption of goods, but the result of quality social relationships and interactions, satisfying work and enough free time.

\subsection{Economic impacts of food waste}

Both producers and consumers are part of the current economic system and interact. This means that consumer preferences are one of the factors influencing the behavior of food producers and the generation of waste. However, the functioning of the economic system is too complex and interwoven with many ties and relationships. The consumption of resources depends not only on the chosen technology of production, subsequent redistribution and distribution, but it is also significantly influenced by the size of final consumption, which is multiplied by the size of the population. This means that it is not possible to strictly separate production and consumption, that is, even an ordinary consumer becomes responsible for the environmental impacts of consumption. Food waste in developed countries also affects pricing policy. Higher waste is associated with influencing demand, which leads to an increase in the price level of food stocks. As a result, people with minimum incomes who cannot afford to spend more money on food are most at risk. The price of food is also largely linked to environmental causes.

The economic value of the food wasted globally is approximately 1000 billion dollars per year, this figure rises to 2600 billion considering the hidden environmental costs that result from the phenomenon [5]. Since food waste represents a major public policy issue, it has recently been included in the United Nations Sustainable Development Goal, "Responsible Consumption and Production", which aims to halve "per capita global food waste at retail and consumer level and reduce food loss along production and supply chains by 2030" [19].

The topic of the impact of food trade is also related to the topic of social entrepreneurship. However, we also encounter other social enterprises, such as social entrepreneurship in agriculture or alternative use of resources. In this case, the "Planet" perspective prevails.The Europe 2020 Strategy and the EU 
Sustainable Developement Strategy are also based on the principles of social entrepreneurship[16].

\section{Zero Waste as a global approach to elimination of food waste}

The name Zero waste comes from an industrial area. There is no consensus on the definition of the term given the diversity of international organizations or scholarly literature dealing with the topic of zero waste from a different perspective.However, in their essence they agree on many aspects. In today's form, the concept is referred to as a visionary goal that needs to be as close as possible.Zero Waste International Alliance [21] says zero waste is: “... an ethical, economic, effective and visionary goal that leads people to change their lifestyles and practices that emulate sustainable natural cycles in which all discarded materials are designed to were reusable as resources for others.Zero waste means designing and managing products and processes to systematically prevent or eliminate the volume of toxicities of waste and materials. " Thus, in recent decades, the concept of zero waste has been presented as an alternative solution to this waste issue [2].This principle of waste minimization through prevention or reduction of waste generation has been adopted by various organizations and cities around the world that have incorporated this ambition into their waste management plan.. The author Bea Johnson in her book: „Zero waste home.“ out five steps that should be taken by a household that wants to significantly reduce its waste and hence the negative impact on the Earth [13].

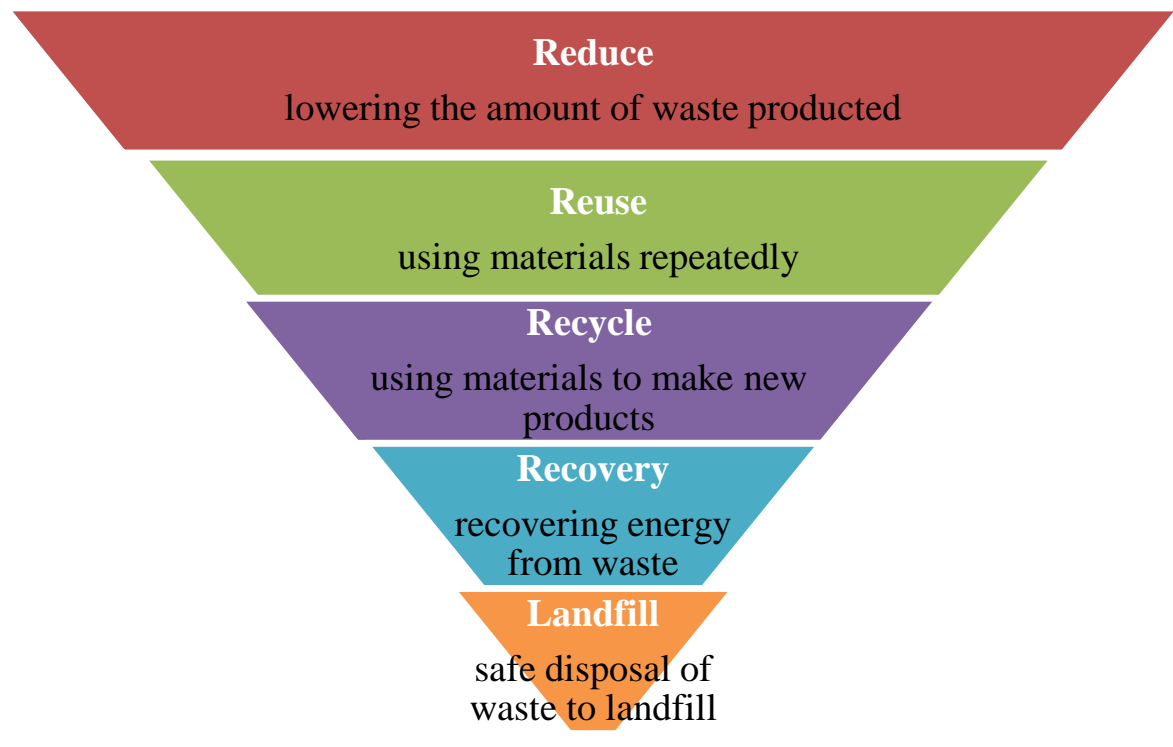

Fig. 2.Steps in Zero Waste[13] 
1 Refuse: Reject what you don't need.The most effective way to avoid waste is tostart rejecting it. Start using the word "NO". Reject promotional items, in-box flyers, plastic shopping bags...[13]

2 Reduce: Reduce what you really need.Let us apply voluntary modesty to our lives. Let's think before every purchase, whether we really need the thing (such as the fifth jeans or a new mobile).Can't we borrow it somewhere (like a drill or a tent)? Let's not forget that our purchase today is our tomorrow's waste[13].

3 Reuse: Reuse and repair.Not everything that goes wrong must fly to the trash immediately. Let's try to fix things and keep using them. Making every new thing requires a lot of energy, water and non-renewable resources on our planet. Let's not waste them. Let's buy things that are designed to last and easily repair when needed. If we can, let's buy second hand (and not just clothing)[13].

And, of course, let's completely eliminate one-off things from our lives. There is a lasting alternative to everything one-off. Fabric shopping bags, cotton handkerchiefs, glass coffee cups...[13]

4 Recycle: Recycle what you cannot renounce, reduce or reuse.Let's learn to sort our waste properly. But let us not forget that recycling is a costly and energy-intensive process with an impact on the environment. In addition, not all materials can be recycled to make something useful again.Therefore, it is most important to prevent waste.Recycling should only come as the fourth - only when we could not refuse, reduce or reuse it[13].

5 Rot: Compost the rest.Up to $40 \%$ of household waste is biodegradable waste.This can be composted and the fertilizer can be used in the garden or on the balcony.You can also compost in a housing estate. There are several options to choose from: set up a community composting site, buy a vermicomposter or an electric composter[13].

In 2018, Slovakia generated more than 14 million tonnes of waste, of which only 2.1 million tonnes was municipal waste.This represents more than 14 million tonnes.This is the amount of waste generated by Slovakia in 2018.Of this, 2.1 million tonnes was municipal waste, which represents $393 \mathrm{~kg}$ per capita per year.And, unfortunately, this figure is growing every year - significantly since $2014[20]$.

Table 1.Development of municipal waste per capita in the Slovak Republic[20]:

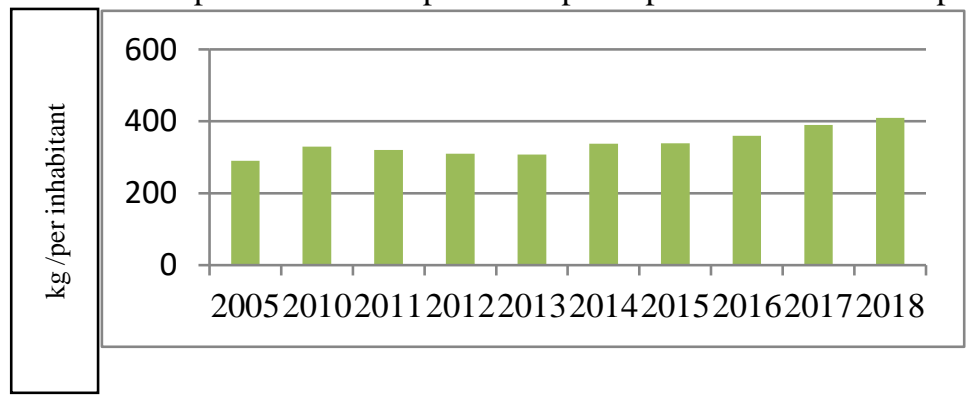


Of this huge amount of waste, we sort and recycle only $29 \%$, ranking it as the last place in the EU. Up to $61 \%$ of municipal waste ends up in landfill and causes soil, surface and groundwater and air pollution. Coincidentally, these are the three basic components we need to live. Consequently, the only sustainable way to deal with this situation is to reduce waste. Simply prevent it from occurring. If it does not, it does not need to be recycled, incinerated or stored forever in a landfill[19].

\section{Conclusions}

Recently, our society is waking up ecologically. More and more people are trying to protect the environment and limit the damage it causes to the planet. Whether we like it or not, we all leave the environmental footprint behind. However, we can at least try to keep it as small as possible. Nevertheless, our grandparents or their parents have not addressed ecology to the extent that it is done today. The way of life was different, more natural, more gentle than it is today - in a period of rapidly changing fashion trends, electronic devices that are perishable in the short term, excess food, plastic, or a lot of motor equipment on the road. Ecology is a problem of our time, of our generation, and therefore cannot be considered as a trend that will pass in a year or two. It is a natural response of society to a question that needs to be addressed urgently. Fortunately, the world is already aware of the harmfulness of plastics and their impact on the environment.

We are aware of the impact of the fashion industry on nature, the harmfulness of mass production of products, instead of driving cars more and more bicycles, we care about animal rights and try not to produce or at least recycle waste. But few people talk about the impact of wasting food on nature.. This is a huge problem for developed countries in the modern world. We no longer have to fight with scarcity or hunger, but on the contrary with surplus. Up to a third of the food we produce never gets into our mouths. Either it is not picked up by farmers during harvesting, is lost when being transported to shops, or simply thrown away. Although we often talk about how we damage nature, for example, with plastics, few people realize how much it can harm decaying food.This produces hazardous greenhouse gases and contributes to global warming. If we were to collect all the discarded food in the world and put the country together, it would be the 3rd largest producer of greenhouse gases on the planet. Our society has set a quite ambitious goal, by 2030 we would like to reduce our waste by 50\%. [5], Its sounds like something impossible, but with a little effort we can really do it.

According to Zero Waste, everyone can contribute to reducing food waste[21]:

- Buy only with a shopping list. Check your groceries at home and prepare a grocery list before shopping. Do not buy impulsively and according to hunger. Prefer unpackaged fruits and vegetables per gramm.

- Checking dates. Consumption of food stored in the household gradually according to the expiration date. Distinguish the terms 'use by' and 'minimum durability'. The date of minimum durability indicates freshness and quality, not harm to health. After this period, the products may still be safe and fit for consumption- Don't buy anything you don't really need!

- Make your menus every day 
- Compost. Compost as an organic material is one way to dispose of the resulting food waste. Compost also includes the necessary food waste, which represents the unprocessable portion of vegetables and fruits. Compost is suitable as a fertilizer for plants [21].

- Keep food remnants in containers in the refrigerator and eat them later- Do not support sales that artificially boost consumption such as two for the price of one [13].

Food wastage is a problem throughout the food chain, and action needs to be taken at all stages to ensure that all stakeholders can benefit. Waste situations can be different. Different causes require different approaches in dealing with them. Each of us plays our role as supporters and reducing waste. Prevention should be particularly emphasized, as preventing wastage is more advantageous in all respects than following it up. In fact, the less food wasted, the fewer the related impacts which would lead to an improvement in the sustainability of the entire food service sector [11]. Only by taking such steps can we ensure the full life of future generations.

\section{References}

1. M. Arsand, A. Parry. Helping Consumers Reduce Food Waste - Retail Survey B.m.: WRAP, ISBN 978-1-84405-476- 3. Available at http://www.wrap.org.uk/sites/files/wrap/Retail_Survey_2015 Summary_Repor t_0.pdf) (2015) (Accessed 13.september 2019)

2. P.H. Connett. The zero waste solution: untrashing the planet one community at a time. (Chelsea Green Publishing, Vermont, 2013)

3. Ensure sustainable consumption and production [online]. Available at http://www.osn.cz/sdg-12-zajistit-udrzitelnou-spotrebu-a-vyrobu/) (2019) (Accessed 11.september 2019)

4. EU actions against food waste - Food Safety - European Commission. Food Safety[online] Available at http://www.food/safety/food_waste/eu_actions_en) (Accessed 11.september 2019)

5. Food Loss and Food Waste. Food and Agriculture Organization of the United Nations [online]. Available at http://www.fao.org/food-loss-and-foodwaste/en/) 2019 (Accessed 13.september 2019)

6. J. Golian, K. Fasiangova, Plytvanie potravinami - etický, ekonomický, sociálny a enviromentálny problém. Bezpecnost a kontrola potravin (XIII. scientific conference with international participation). Slovak University of Agricultures, Slovakia, 23-28 (2016)

7. E. Graham-Rowe, D.C. Jessop, P. Sparks, P, Identifying motivations and barriers to minimising household food waste. Resouces Conservation Recycling 84, 15-23, (2014)

8. M. Griffin, J. Sobal, T.A. Lyson, An analysis of a community food waste stream. Agriculture and Human Values 26 , 67-81, (2009).

9. J. Gustavsson, C. Cederberg, U. Sonesson, Global Food Losses and Food Waste, Swedish Institute for Food and Biotechnology. SIK. Gothenburg, Sweden, (2011) 
10. G. Hawkins, Plastic bags : Living with rubbish. International Journal of Cultural Studies 4, 5-23 (2001)

11. L. Heikkilä, A. Reinikainen, J.M Katajajuuri, K. Silvennoinen, H. Hartikainen, Elements affecting food waste in the food service sector. Waste Management 56, 446-453 (2016)

12. D. Hoornweg, P. Bhada-Tata, C. Kennedy, Environment: waste production must peak this century. Nature 502, 615-617, (2013)

13. B. Johnson, Zero Waste Home: The Ultimate Guide to Simplifying Your Life by Reducing Your Waste. Amazon Digital Services 306, (2013)

14. E.F. Lambin, P. Meyfroidt, Global land use change, economic globalization, and the looming land scarcity. Proc. Natl. Acad. Sci. Unit. States Am. 108, 3465-3472. (2011)

15. N. Mirabella, V. Castellani, S. Sala, Current options for the valorization of food manufacturing waste: a review. Journal of Clenaer Production 65, 28-41 (2014)

16. M.Nova. Social enterprise used as a tool for supporting regions.Die

Wirtschaftliche Entwicklung Europäischer regionen in der ausbildungs - und arbeitsmarktpolitik - Übergange und strategien. Uzhorod: TOV RiK-U., 7785. (2018)

17. J. Parfitt, M. Barthel, S. Macnaughton, Food waste within food supply chains: quantification and potential for change to 2050. Philosophical transactions of the royal society b-biological sciences $\mathbf{3 6 5}$, 3065-3081. (2010)

18. L. Principato, L. Secondi, C.A. Pratesi, Reducing food waste: an investigation on the behaviour of Italian youths. British Food Journal 117, 731-748. (2015)

19. L. Principato, L. Secondi, C.A. Pratesi, Towards Zero Waste: an Exploratory Study on Restaurant managers. International Journal of Hospitality Management 70, 130-137 (2018)

20. Waste in the Slovak republic Available at file:///E:/clanok\%20WOS/Odpadky_v_Slovenskej_republike_za_rok_2017.pdf ) (2018) (Accessed 10.september 2019)

21. Zero Waste International Alliance. Available at http://www.zwia.org/aboutus/ (Accessed 1.september 2019) (2015) 